УДК 373.5.015.31 : 173.5

DOI: $\underline{10.35619 / \text { iiu.v2i11.240 }}$

Шахрай Валентина

доктор педагогічних наук, доцент, завідувачка лабораторії інституційного виховання Інституту проблем виховання НАПН України, м. Київ, Україна

ORCID: 0000-0003-2433-0357 e-mail:vshakhrai@ukr.net

\title{
ФОРМУВАННЯ ГОТОВНОСТІ СТАРШОКЛАСНИКІВ ДО ВІДПОВІДАЛЬНОГО БАТЬКІВСТВА: ОСНОВНІ ПОНЯТТЯ ДОСЛІДЖЕННЯ
}

Анотація. У статті наголошено на важливості дослідження проблеми формування готовності старшокласників до відповідального батьківства в умовах, коли батьківство в Україні має низку негативних проявів (насильство над дітьми, високий рівень розлучення подружніх пар, раннє материнство тощо). До основних понять, що розкривають процес формування готовності старшокласників до відповідального батьківства, віднесено: батьківство, відповідальне батьківство, позитивне ставлення до батьківства, репродуктивна культура, батьківська любов, батьківська компетентність, готовність до відповідального батьківства старшокласників. Визначено, що відповідальне батьківство - це інтегративне утворення особистості, що включає сукупність позитивних ставлень, установок і очікувань індивіда як батька, батьківські почуття, насамперед батьківську любов, оволодіння педагогічними компетенціями. 3'ясовано, що готовність до відповідального батьківства старшокласників передбачає сформованість у них комплексу якостей, що поєднує позитивне ставлення до батьківства, наявність знань, навичок $\mathrm{i}$ вмінь 3 основ репродуктивної культури і сімейної педагогіки, емоційну розвиненість та усвідомлення відповідальності, як майбутнього батька, перед дітьми, сім'єю, суспільством. У висновках вказано завдання подальших розвідок - визначити форми, методи виховної роботи 3 формування готовності старшокласників до відповідального батьківства на основі розглянутих в статті понять.

Ключові слова: батьківство, відповідальне батьківство, готовність, формування, старшокласники, позитивне ставлення до батьківства, батьківська любов, батьківська компетентність.

Постановка проблеми. Відповідальне батьківство $є$ одним 3 основних чинників належної соціалізації молодого покоління, засвоєння культурних норм, ефективного розвитку, самореалізації. Без батьківської відповідальності не сформуються гуманні дитячобатьківські стосунки, що грунтуються на повазі, розумінні, підтримці один одного. Можемо стверджувати, що відповідальне батьківство $є$ важливою соціальною проблемою і повинно бути в колі зору суспільства, освітніх закладів, сім'ї. Слід зазначити, що сучасний стан батьківства в Україні певною мірою є незадовільним. Це підтверджується фактами насильства в сім’ї, що чиниться насамперед щодо дітей, високим рівнем розлучень, що негативно впливає на різні сторони дитячого життя, невмінням і небажанням батьків здійснювати повноцінне сімейне виховання, випадками доволі ранньої народжуваності, що характеризується неготовністю (емоційною, матеріальною) батьків дитини (здебільшого 
однією матір'ю) до належного догляду та розвитку дитини. Доходимо висновку, що «філософія відповідального батьківства має стати основою як соціальних практик, так $\mathrm{i}$ сучасної сімейної політики, забезпечити іiі орієнтацію на задоволення інтересів батьків і дітей, на розвиток людського та соціального капіталу» (Думанська, 2015, с. 77).

Тому важливим $\epsilon$ наукове обгрунтування сутності відповідального батьківства, способів, методів його формування у молоді, насамперед у представників ранньої юності старшокласників, які за своїми фізичними та соціально-психологічними характеристиками вже готові здійснювати перші кроки стосовно майбутнього батьківства і проявляється, зокрема, в їхніх планах, мріях, ціннісних орієнтаціях, соціальній поведінці. Осмислення цієї проблеми спрямувало лабораторію інституційного виховання Інституту проблем виховання НАПН України до вибору теми дослідження: «Формування готовності старшокласників до відповідального батьківства».

Концепція дослідження (система ідей, поглядів щодо його здійснення) включає три складники: методологічний, теоретичний, технологічний. Методологічний є сукупністю наукових підходів до виконання вказаного дослідження, таких як: аксіологічний, особистісно-орієнтований, компетентнісний, соціально-середовищний, гендерний. Теоретичний складник зумовлює визначення вихідних понять, які, передусім, розкривають сутність і структуру поняття «відповідальне батьківство», що і буде предметом розгляду в цій статті. Технологічний складник дослідження передбачає обгрунтування та експериментальну перевірку педагогічних умов та змістового і методичного забезпечення формування готовності старшокласників до відповідального батьківства.

Аналіз останніх досліджень 3 проблеми. Питання відповідального батьківства, формування його у різних груп молоді (старшокласники, студенти, молоді сім'ї) розглядається в дослідження Є. Свдокимова, М. Корольова, Л. Повалій, Л. Яценко та ін. (Евдокимова, 2015; Королев, 2010; Повалій, 2015; Яценко, 2013). Важливими є праці О. Безрукова, В. Думанської, Р. Овчарової, Л. Слюсар та ін., в яких розкриваються теоретичні аспекти батьківства (Безрукова, 2017; Думанська, 2015; Овчарова, 2005; Слюсар, 2016). Дослідження А.Бєлінської, Т.Шапошникової) (Белинская, 2017; Шапошникова, 2010) висвітлюють відповідальне батьківство як педагогічний феномен. Доволі цінними для здійснення дослідження формування готовності старшокласників до відповідального батьківства є погляди В. Сухомлинського (1976 a, 1976 b), в яких розкрито як розуміння сутності батьківства, так і шляхи виховання готовності до нього в підлітковому та юнацькому віці.

Мета статті - на основі аналізу різних наукових поглядів уточнити сутність відповідального батьківства, з'ясувати основні поняття, що його характеризують, на базі чого будуть в подальшому визначатися зміст, форми, методи роботи зі старшокласниками.

Виклад основного матеріалу дослідження. На нашу думку, поняттями, що дають можливість розкрити особливості формування готовності старшокласників до відповідального батьківства є: батьківство, відповідальне батьківство, позитивне ставлення до батьківства, репродуктивна культура, батьківська любов, батьківська компетентність, готовність до відповідального батьківства старшокласників.

Розпочнемо розгляд з найбільш загального поняття - батьківство. Сутність батьківства розкривається у низці досліджень (Овчарова, 2005; Слюсар, 2016; Шапошникова, 2010). Широко підтримуваним дослідниками є визначення батьківства, здійснене Р. Овчаровою: «Батьківство - інтегральне психологічне утворення особистості (батька і / або матері), у тому числі сукупність ціннісних орієнтацій батька, установок і очікувань, батьківських 
почуттів, ставлень і позицій, батьківської відповідальності та стилю сімейного виховання» (Овчарова, 2005, с. 13).

На думку Л. Слюсар, батьківство є поєднанням формальних і неформальних норм i правил стосунків між батьками та їх дітьми. Неформальні норми та правила батьківства, які регулюють його психологічні, емоційні, низку фізичних аспектів, є особливо важливими, оскільки грунтуються на природному компоненті фізичної й емоційної взаємозалежності та взаємодії батьків і нащадків, наявному у певній формі у всіх високорозвинених представників природного світу (Слюсар, 2016, с. 28).

Характеризуючи батьківство, дослідники зазначають, що воно не просто поєднує материнство і батьківство, а означає надіндивідуальне ціле, яке виходить за межі індивіда, тоді як «материнство» і «батьківство» стосуються окремої особистості (Повалій, 2015; Овчарова, 2005; Яценко, 2013 та ін.). Важливим є розуміння, що батьківство - це динамічний процес, якісна зміна батьківських ролей і почуттів залежно від віку дитини, що створює для батьків можливості постійного розвитку й самовдосконалення.

Ми вважаємо сутність батьківства насамперед у реалізації ним соціалізаційної і виховної функцій, а тому визначаємо батьківство як специфічну соціальну діяльність батьків і матерів щодо виховання і соціалізації дітей, що передбачає переживання батьками широкого спектру батьківських почуттів та здатність до гармонійної взаємодії з власними дітьми, їх підготовку до належного функціонування в соціальному та природному середовищі. Підтримуємо думку О. Безрукової, що у молодого покоління слід формувати цінності батьківства, які включають насамперед переконання про цінність дітей і ставлення до них; мотивації дітонародження, планування й організацію народження дітей; якість турботи $\mathrm{i}$ виховання; про те, як повинні будуватися взаємини між батьками і дітьми; які якості необхідно виховувати в дітях (Безрукова, 2017, с. 90).

У сучасний період відбувається модернізація інституту батьківства, у якому великого значення набуває самореалізація особистості у процесі виконання батьківських функцій. Батьківство дедалі більше «виходить за біологічні межі», тобто може бути не пов'язане (чи пов'язане лише частково) зі шлюбом та біологічними (кровно-родинними) відносинами: усиновлення дитини, батьківство 3 використанням деяких репродуктивних технологій (донорства статевих клітин, сурогатного материнства). Такі форми батьківства іноді визначають як «соціальне батьківство» (Слюсар, 2016, с. 31).

Батьківство, на думку О. Безрукової, проявляється в різних моделях: традиційній, солідарній, делегуючій, невизначеній (Безрукова, 2017, с. 91). Переконані, що реалізація батьківства найбільш повно відбувається за умови прийняття i використання його солідарної моделі.

Для свого повноцінного здійснення батьківство має бути відповідальним, що $є$ провідною умовою забезпечення всебічного розвитку дитини. Відповідальність пов'язана насамперед зі здатністю індивіда усвідомлювати свій обов'язок перед кимось (у даному випадку перед дітьми) та готовністю і вмінням виконувати взятий на себе обов'язок в реальних життєвих ситуаціях. Можемо стверджувати, що відповідальне батьківство - це інтегративне утворення особистості, що включає сукупність позитивних ставлень, установок і очікувань індивіда як батька, який глибоко усвідомлює свій обов'язок перед дитиною, іiї теперішнім і майбутнім, батьківські почуття, насамперед батьківську любов, оволодіння педагогічними компетенціями, що дають можливість здійснювати повноцінне сімейне виховання та сприяти позитивній соціалізації дітей.

У структурі відповідального батьківства ми виокремлюємо насамперед позитивне ставлення до батьківства, яке розуміємо як сформованість в індивіда уявлень про сферу 
батьківства, розуміння батьківських обов'язків і можливостей й спрямованість на їх реалізацію, як стан емоційної готовності до виконання батьківських функцій. До ознак, що характеризують позитивне ставлення особи до батьківства, можуть бути віднесені: емоційна привабливість батьківства (задоволення, радість, щастя); пріоритетність батьківства (батьківство як дарунок або обов'язок); очікування батьківства (батьківство як можливість самореалізуватися, піклуватися про дитину) (Евдокимова, 2015, с. 20).

Важливим складником відповідального батьківства на наше переконання, є належний рівень репродуктивної культури членів подружжя (майбутніх батьків), адже він забезпечує насамперед фізичне здоров'я дітей. О. Васюта дає таке визначення репродуктивної культури: це сукупність знань, умінь, цінностей, що регулюють репродуктивну поведінку людини як системи дій та відносин з відтворення людського роду в рамках наявних біологічних і соціальних можливостей. Дослідниця наголошує, що, незважаючи на великий обсяг і широку доступність інформації про доцільне зачаття, виношення і народження дитини (щоб вона 3 матір'ю були здорові і щасливі), чи навпаки, про уникнення зачаття до настання сприятливих умов, знання такого характеру не $\epsilon$ часто затребуваними, що свідчить про низький рівень репродуктивної культури молоді (Васюта, 2015, с. 133). А це свідчить про несформованість батьківської відповідальності у сфері репродуктивного здоров'я, що може призводити до інвалідності дітей, зниження можливостей для їхньої повноцінної соціалізації, до значних сімейних негараздів.

Однією з найхарактерніших ознак батьківства $є$ комплекс батьківських почуттів, у якому необхідно виділити насамперед батьківську любов. Враховуючи позицію Т. Шапошнікової, батьківську любов ми розуміємо як почуття батька до своєї дитини, особливе переживання кровної спорідненості і продовження себе в дитині, відповідальності за іiі долю, що транслюється через ставлення до неї, яке може динамічно змінюватися в процесі здійснення батьківства. До ознак батьківської любові можна віднести: тепле емоційне ставлення, наявність постійної потреби у спілкуванні, турбота, знання об'єкта любові, жертовність, співчуття і співпереживання у важкі моменти (Шапошникова, 2010, с. 89).

У дослідженнях виокремлюють батьківський та материнський типи любові, розвиваючи насамперед думки Е. Фромма, які він висловив у книзі «Мистецтво любові» (Фромм, 2017, с. 72-76). Більшість дослідників підкреслюють надзвичайну важливість батьківської любові як для емоційного розвитку дітей, так і для самоудосконалення батьків. Водночас слід зауважити, що не завжди батьківська любов позитивно впливає на дітей, сприяє їхному морально-духовному зростанню. Про це наголошував видатний педагог В. Сухомлинський: «без мудрості батьківської педагогіки любов матері i батька калічить дітей» (Сухомлинський, 1976 b, с. 542). Такою шкідливою для дитини є любов замилування, любов деспотична, любов відкупу.

Ми пов'язуємо відповідальне батьківство із здатністю батьків до гармонійної любові (широка гама емоційних переживань батьків у ставленні до дитини, високий ступінь відчуття емоційного стану дитини, здатність до співпереживання, рівність та товариськість у взаєминах батьків і дитини). Як зазначає Т. Шапошнікова, любов гармонійного типу не $\epsilon$ жертовною, вона проявляється у рівності батька і дитини, в наявності товариських взаємин між ними, в демократичності батька (Шапошникова, 2010, с. 90).

Батьківська компетентність як складник відповідального батьківства є відображенням здатності батьків здійснювати повноцінне сімейне виховання, забезпечувати розумовий, фізичний, моральний, трудовий, естетичний розвиток дітей. Беручи до уваги думки щодо сутності батьківської компетентності (Белинская, 2017; Повалій, 2015), батьківську компетентність розуміємо як індивідуально-психологічне утворення, що відображається в 
єдності теоретичної і практичної готовності особи до здійснення батьківської діяльності та характеризується належним рівнем знань про процеси виховання i навчання, про міжособистісні взаємини $з$ дитиною, про специфіку психічного розвитку дитини в умовах норми і патології, про її вікові особливості, про способи та технології педагогічного впливу у реальних життєво-сімейних ситуаціях і вмінням ці знання використовувати у взаємодії 3 дитиною.

Визначені вище поняття, що стосуються батьківства та відповідального батьківства, у своїй сукупності розкривають зміст ще одного важливого поняття нашого дослідження готовність старшокласників до відповідального батьківства. При цьому маємо враховувати те, що описані поняття стосуються насамперед батьків, які вже мають власних дітей, тобто зрілого батьківства. У готовність старшокласників до відповідального батьківства маємо включити насамперед ті елементи відповідального батьківства, що здатні засвоїти молоді люди цього вікового періоду, які, в переважній більшості, ще не мають досвіду реального батьківства. Тобто можемо говорити насамперед про потенційне батьківство.

На нашу думку, готовність до відповідального батьківства старшокласників передбачає сформованість у них комплексу якостей, що поєднує позитивне ставлення до батьківства, наявність знань, навичок і вмінь з основ репродуктивної культури і сімейної педагогіки, емоційну розвиненість та усвідомлення відповідальності, як майбутнього батька, перед дітьми, сім'єю, суспільством. До готовності старшокласників до відповідального батьківства віднесемо їх налаштованість на солідарну модель батьківства, усвідомлення необхідності прояву у ставленні до своїх майбутніх дітей гармонійної любові.

У дослідженнях наголошується, що становлення відповідального батьківства у старшокласників передбачає їх теоретичну і практичну готовність (Королев, 2010, с. 24-25). Теоретична готовність має такі критерії: знання біологічних і медичних аспектів, пов'язаних iз зачаттям; знання і розуміння юридичних аспектів, пов'язаних з виконанням батьківських обов'язків; усвідомлене бажання мати і виховувати дітей, розуміння пов'язаної з цим відповідальності; уявлення про способи догляду за дитиною, зміст, методи сімейного виховання. До ознак практичної готовності віднесено: спрямованість на отримання професії як основи створення побутових та фінансових можливостей для повноцінного догляду дитини; уміння проєктувати і планувати процес самопідготовки до виконання ролі батька/матері; уміння управляти власним психічним станом (емоціями) та поведінкою; розвиток навичок догляду за дитиною; здатність до здійснення належного сімейного виховання.

Важливо брати до уваги позицію В. Сухомлинського, що готовність до відповідального батьківства нерозривно пов'язана із моральною готовністю, здатністю старшокласників «брати на себе труд відповідальності, тягар обов'язку за життя, здоров'я, душевний спокій, благополуччя інших людей» (Сухомлинський, 1976 а, с. 87).

Висновки і перспективи подальших розвідок. Сучасне суспільство, зважаючи на проблеми, які переживає сім'я, на складність батьківсько-дитячих взаємин, потребує відповідального батьківства. Під відповідальним батьківством розуміємо інтегроване утворення особистості, що включає сукупність позитивних ставлень, установок і очікувань індивіда як батька, батьківські почуття, оволодіння педагогічними компетенціями, що дають змогу здійснювати повноцінне сімейне виховання та сприяти позитивній соціалізації дітей. Основними поняттями, що характеризують відповідальне батьківство старшокласників, вважаємо такі: позитивне ставлення до батьківства, батьківську любов (для старшокласників передумовою такої любові є дружба з ровесниками, любов до інших, 
батьків), належний рівень репродуктивної культури, батьківську компетентність (оволодіння основами сімейного виховання). З'ясування сутності цих понять дає можливість визначити форми, методи виховної роботи 3 формування готовності старшокласників до відповідального батьківства, що буде завданням наших подальших розвідок.

\section{СПИСОК ВИКОРИСТАНИХ ДЖЕРЕЛ}

Думанська, В. (2015). Відповідальне батьківство: теоретичний аспект. Демографія та соиіальна економіка, 3 (25), с. 75-85.

Евдокимова, Е. (2015). Формирование иенностного отношения к родительству $у$ студентов вуза. Кандидат психологических наук. Пятигорский госуд. лингвистический университет. 24 с.

Королев, М. (2010). Формирование ответственного родительства как педагогическая проблема. Перспективы науки, 8 (10), с. 22-26.

Повалій, Л. (2015). Формування у старшокласників відповідального батьківства як сімейної цінності. Молодий вчений, 2 (17), с. 295-298.

Яценко, Л. (2013). Сутнісні характеристики готовності до відповідального батьківства. Теоретико-методичні проблеми виховання дітей та учнівської молоді. Вип. 17 (2), с. 513 521.

Безрукова, О. (2017). Ценности детей и родительства: межпоколенческая динамика. Социологический журнал, 23 (1), сс. 88-110.

Овчарова, Р. (2005). Психология родительства : учеб. пособие для студ. высш. учеб. заведений. Москва: Издательский центр «Академия». 368 с.

Слюсар, Л. (2016). Батьківство у системі відносин інституту сім'ї: сучасні трансформації, їх причини та наслідки. Демографія та соціальна економіка, 2 (27), с. 26-38.

Белинская, А. (2017) Ответственное родительство как психолого-педагогический феномен. Новая наука: Теоретический и практический взгляд, 1 (3), с. 32-35.

Шапошникова, Т. (2010). Родительство как педагогический феномен. Вестник НГУ. Серия: Педагогика, 12 (2), сс. 86-91.

Сухомлинський, В. (1976 а). Вибрані твори : в 5 m. Київ : Рад. шк. Т. 1. 654 с.

Сухомлинський, В. (1976 b). Вибрані твори : в 5 т. Київ : Рад. шк. Т. 2. 670 с.

Васюта, О. (2015). Розвиток репродуктивної культури студентської молоді. Вісник Чернігівського національного педагогічного університету. Серія Педагогічні науки, 124, c. $132-135$.

Фромм, Е. (2017). Мистеитвво любові / пер. з англ. В. Кучменко. Харків: Книжковий Клуб «Клуб Сімейного Дозвілля». 192 с.

\section{REFERENCES}

Dumanska, V. (2015). Vidpovidalne batkivstvo: teoretychnyi aspect [Responsible Parenthood: Theoretical Aspect]. Demohrafiia ta sotsialna ekonomika, 3(25), s. 75-85. (in Ukrainian)

Evdokimova, E. (2015). Formirovanie tsennostnogo otnosheniya k roditelstvu u studentov vuza [Formation of Value Attitude Towards Paternity for University Students]. Kandidat psihologicheskikh nauk. Pyatigorskiy gosud. lingvisticheskiy universitet. 24 s. (in Russian)

Korolev, M. (2010). Formirovanie otvetstvennogo roditelstva kak pedagogicheskaya problema [Development of Responsible Parenthood as a Pedagogical Problem]. Perspektivyi nauki, 8 (10), s. 22-26. (in Russian) 
Povalii, L. (2015). Formuvannia u starshoklasnykiv vidpovidalnoho batkivstva yak simeinoi tsinnosti [Shapimg of Responsible Parenthood for Teenager's as a Family Value]. Molodyi vchenyi, 2 (17), s. 295-298. (in Ukrainian)

Yatsenko, L. (2013). Sutnisni kharakterystyky hotovnosti do vidpovidalnoho batkivstva [The Essence Descriptions of Readiness to Responsible Paternity]. Teoretyko-metodychni problemy vykhovannia ditei ta uchnivskoi molodi, 17 (2), s. 513-521. (in Ukrainian)

Bezrukova, O. (2017). Tsennosti detey i roditelstva: mezhpokolencheskaya dinamika. [The Values of Children and Parenthood: Intergenerational Dynamics]. Sotsiologicheskiy zhurnal, 23 (1), s. 88-110. (in Russian)

Ovcharova, R. (2005). Psihologiya roditelstva [Psychology of Parenthood]. Moskva: Izdatelskiy tsentr "Akademiya”. 368 s. (in Russian)

Sliusar, L. (2016). Batkivstvo u systemi vidnosyn instytutu sim'i: suchasni transformatsii, yikh prychyny ta naslidky [Parenthood in the System of Relations of Family Institute: Modern Transformations, Their Causes and Consequences]. Demohrafiia ta sotsialna ekonomika, 2 (27), s. 26-38. (in Ukrainian)

Belinskaya, A. (2017). Otvetstvennoe roditelstvo kak psihologo-pedagogicheskiy fenomen [Responsible Parenthood as a Psychological and Pedagogical Phenomenon]. Novaya nauka: Teoreticheskiy i prakticheskiy vzglyad, 1 (3), s. 32-35. (in Russian)

Shaposhnikova, T. (2010). Roditelstvo kak pedagogicheskiy fenomen [Parenthood as a Pedagogical Phenomenon]. Vestnik NGU. Seriya: Pedagogika, 12 (2), s.86-91. (in Russian)

Sukhomlynskyi, V. (1976 a). Vybrani tvory : v 5 t. [Selected Works: in 5 vol.]. Kyiv : Rad. shk. T. 1.654 s. (in Ukrainian)

Sukhomlynskyi, V. (1976 b). Vybrani tvory : v 5 t. [Selected Works: in 5 vol.]. Kyiv: Rad. shk. T. 2. 670 s. (in Ukrainian)

Vasiuta O. (2015). Rozvytok reproduktyvnoi kultury studentskoi molodi [Development of Reproductive Culture of Students]. Visnyk Chernihivskoho natsionalnoho pedahohichnoho universytetu. Seriia Pedahohichni nauky, 124, s. 132-135. (in Ukrainian)

Fromm, E. (2017). Mystetstvo liubovi [The Art of Loving] / per. z anhl. V. Kuchmenko. Kharkiv: Knyzhkovyi Klub "Klub Simeinoho Dozvillia”. 192 s. (in Ukrainian)

\title{
DEVELOPMENT OF HIGH SCHOOL STUDENTS' PREPAREDNESS TO RESPONSIBLE PARENTHOOD: BASIC CONCEPTS OF THE STUDY
}

\author{
Valentyna Shakhrai \\ Doctor of Sciences (in Pedagogy), Associate Professor, \\ Head at the Laboratory of Institutional Education, \\ Institute of Problems of Education of the NAES of Ukraine, \\ Kyiv, Ukraine \\ ORCID: 0000-0003-2433-0357 \\ e-mail:vshakhrai@ukr.net
}

\begin{abstract}
The article emphasizes the importance to explore the problem of high school students' preparedness to responsible parenthood in terms of such negative aspects as child abuse, high rate of divorce among married couples, early motherhood etc. Basic concepts of responsible parenthood include such notions as parenthood, responsible parenthood, positive approach to parenthood, reproductive culture, parental love, parental competence, high school students' preparedness to responsible parenthood. Responsible parenthood is determined as integral
\end{abstract}


background of individual that includes the whole complex of positive approach, facilities and expectations of the individual who is profoundly sensible of his responsibility towards the present and the future of his child, parental feelings, primarily parental love and development of a basic pedagogical competence that allows to provide a meaningful family education and contributes to positive socialization of children. High school students' preparedness to responsible parenthood is determined as the wide range of capacity that combines positive approach to parenthood, reproductive culture, family pedagogics knowledge and skills, emotional development and conscience of responsibility to children as a future father, family and society. High school students' preparedness to responsible parenthood includes concentration on the loyal parenthood model and realizing the importance of showing balanced love towards his future children. High school students' responsible parenthood maturity usually involves theoretical and practical aspects. Conclusions specify that the future aim of investigations that includes identification of forms and methods of educational work, focused on high school students' preparedness to responsible parenthood, would be discovered on the basis of concepts mentioned in the article.

Keywords: parenthood, responsible parenthood, preparedness, development, high school students, positive approach to parenthood, parental love, parental competence.

Стаття надійшла до редакиії 06.05.2020 p. 